\title{
Prevalence of Blackleg and Pathogenicity Groups of Leptosphaeria maculans in North Dakota
}

Achala Nepal, S. Markell, and J. Knodel, Department of Plant Pathology, North Dakota State University, Fargo 58108; C. A. Bradley, Department of Crop Sciences, University of Illinois, Urbana 61801; and L. E. del Río Mendoza, Department of Plant Pathology, North Dakota State University, Fargo 58108

\begin{abstract}
Nepal, A., Markell, S., Knodel, J., Bradley, C. A., and del Río Mendoza, L. E. 2014. Prevalence of blackleg and pathogenicity groups of Leptosphaeria maculans in North Dakota. Plant Dis. 98:328-335.

Blackleg, caused by Leptosphaeria maculans, was first reported on canola (Brassica napus) in North Dakota in 1991. In 2003, L. maculans strains of previously unreported pathogenicity groups (PG) were discovered in the region. Since then, however, little has been known about the prevalence of L. maculans in the state. The objectives of this study, therefore, were to characterize the prevalence of blackleg and of L. maculans PGs in North Dakota. Prevalence was assessed in 2004, 2007, and 2009 in 572 fields. PG determination for 216 L. maculans isolates retrieved from blackleg symptomatic stems during that period

was achieved on a set of B. napus differential cultivars. Blackleg prevalence increased from 28\% in 2004 to 63 and $74 \%$ in 2007 and 2009, respectively. Similarly, the number of fields with blackleg incidences $>30 \%$ increased from $4 \%$ in 2004 to 12 and $23 \%$ in 2007 and 2009, respectively. In all years, PG-4 was the predominant group, while PG-2, once predominant, accounted for $<2 \%$ of isolates. Increase in the prevalence and incidence of blackleg as well as the frequency of virulent PGs over the last 10 years is a serious threat to the canola industry of the region.
\end{abstract}

Blackleg, caused by Leptosphaeria maculans (Desm.) Ces. \& De Not. (anamorph Phoma lingam (Tode ex Fr.) Desm.), is one of the most important diseases affecting oilseed rape (Brassica napus) production worldwide (31). Recorded prevalence of $L$. maculans dates back 85 years in Australia, 65 years in Europe, 35 years in Canada, and approximately 20 years in the United States of America $(2,16,24,28)$. The disease has caused significant yield losses in Australia (14), the United Kingdom (10), and France (1). Oilseed rape genotypes with low erucic acid and glucosinolates contents, also known as canola, that were introduced to North Dakota in early 1980 are also affected by this pathogen. In North Dakota, where canola is planted in early May, yield losses of up to 45 to $50 \%$ in severely infected fields in canola-growing regions of the state have been reported $(9,20)$.

Blackleg is reappearing as a serious threat to the canola industry in North Dakota. In 1991, a blackleg outbreak was detected in the northeastern corner of the state with field incidences that ranged between 8 and 68\% (16). Leptosphaeria isolates retrieved from affected fields were inoculated on a set of three B. napus differential cultivars to identify their pathogenicity groups (22). Only strains belonging to PG-1 and PG-2 were detected, with PG-2 being the most prevalent group (16). Isolates belonging to PG-1 have been reclassified as L. biglobosa (26). By 1993, the most popular cultivar, Westar, which does not carry L. maculans resistance genes, had been abandoned (16). By the end of the 1990s, most commercial genotypes carried genes for resistance against PG-2 (4), and no new blackleg outbreaks had been reported. In 2003, Bradley et al. (6) detected the presence of PG-3 and PG-4 strains in canola stems showing typical blackleg cankers. At that time, however, PG-3 and PG-4 accounted for less than 5 and 1\% of all isolates evaluated, respectively; the remaining isolates belonged to PG-2 (6). In 2009, several blackleg outbreaks were detected in

Corresponding author: L. E. del Río Mendoza,

E-mail: luis.delrio-mendoza@ndsu.edu

Accepted for publication 4 September 2013.

http://dx.doi.org/10.1094/PDIS-04-13-0458-RE

(C) 2014 The American Phytopathological Society various North Dakota counties. The virulence phenotypes of more than 100 isolates retrieved from infected canola stems collected from these fields indicated that only $3 \%$ of them belonged to PG-2, whereas strains of PG-4 and PG-3 accounted for 51 and $25 \%$ of the remaining isolates, respectively (9). While this information provides strong evidence that a shift in PG prevalence is under way, the extent of the change is still unclear. Thus, the objective of this study was to characterize the changes in PG prevalence that have occurred in North Dakota since 2004.

\section{Materials and Methods}

Weather data collection. Hourly data for air temperature and precipitation were obtained from 27 North Dakota Agricultural Weather Network (NDAWN) weather stations located across the areas where samples were collected. Data retrieved corresponded to the period between 15 May and 15 June of each year between 1992 and 2009, when the plants were between the seedling and rosette growth stages.

Plant sample and disease data collection. Canola stem samples were collected from 21 North Dakota counties in 2004 and 2007, and from 20 counties in 2009 (Fig. 1). The number of fields sampled was roughly proportional to canola hectarage planted the prior year in each county, with one field selected per 2,025 ha. Selection of fields within each county was arbitrary, considering only fields at least $4.5 \mathrm{~km}$ apart. Samples were collected in late August to early September when the crop was in the swath and the stubble was freshly cut. Five freshly swathed stems were pulled from 10 arbitrarily selected locations within each field, with a total of 50 stems per field collected. The crown and the roots of each stem were visually inspected for blackleg symptoms, and the incidence of infected plants was recorded. Affected plants were identified by the presence of typical gray to black stem cankers near the soil line that sometimes had pycnidia on them (20). Blackleg symptomatic tissues were brought to the laboratory to confirm the diagnosis and to isolate the pathogen for further studies.

Isolation of Leptosphaeria spp. and inoculum preparation. A total of 216 Leptosphaeria spp. isolates were retrieved from samples collected from 12 counties in 2004, 14 counties in 2007, and 11 counties in 2009. Single-spore cultures of these isolates were prepared as described in del Rio Mendoza et al. (9). Briefly, the infected tissues were washed with running tap water to remove the 
debris from the stem surface and then lightly tapped with paper towels to remove excess moisture. Infected portions of the stem were cut and surface disinfested by immersing in either $100 \%$ commercial bleach or $30 \%$ aqueous solution of the bleach for 10 to $30 \mathrm{~s}$ depending upon the condition of the sample. Disinfested tissues usually containing pycnidia were scraped off using a sterile scalpel and suspended in sterile distilled water. About $0.5 \mathrm{ml}$ of the suspension was streaked onto full strength V8 medium amended with streptomycin and penicillin. The medium was prepared with $837 \mathrm{ml}$ of distilled water, $163 \mathrm{ml}$ of V8 juice, $15 \mathrm{~g}$ of agar (BactoAgar, Becton Dickinson and Co., Sparks, MD), and $3 \mathrm{~g}$ of $\mathrm{CaCO}_{3}$. The medium was adjusted to $\mathrm{pH} 7.2$ by adding $1 \mathrm{M} \mathrm{NaOH}$. The medium was sterilized by autoclaving at $120^{\circ} \mathrm{C}$ and $103.4 \mathrm{kPa}$ for $20 \mathrm{~min}$ and then amended with $7.5 \mathrm{ml} / \mathrm{liter}$ streptomycin (10 $\mu \mathrm{g} / \mathrm{ml})$ and $7.5 \mathrm{ml} / \mathrm{liter}$ penicillin $(10 \mu \mathrm{g} / \mathrm{ml})$. The inoculated medium was incubated under constant white light for 3 to 4 days at $21^{\circ} \mathrm{C}$. Single-spore colonies were transferred to new plates containing full strength V8 medium prepared as described but without antibiotic and incubated for 2 weeks as described. The identity of Leptosphaeria isolates was confirmed by colony, pycnidia, and
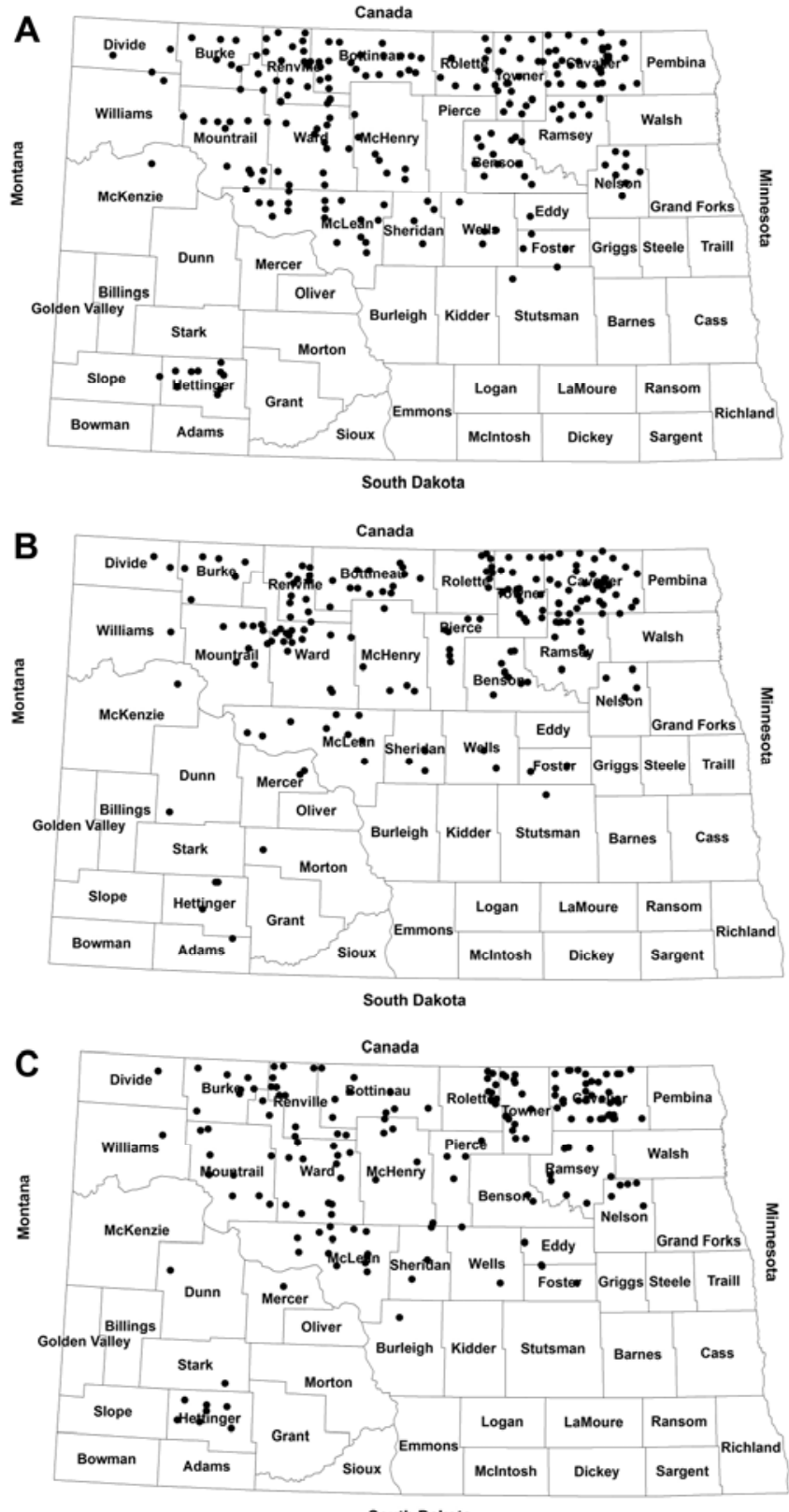

South Dakota

Fig. 1. Location of commercial canola fields in North Dakota sampled for blackleg incidence and severity in A, 2004, B, 2007, and C, 2009. pycnidiospores morphology. Single-spore colonies were stored at $-80^{\circ} \mathrm{C}$ for future use.

Spores from 2-week-old colonies growing in V8 medium were suspended in $5 \mathrm{ml}$ of sterile distilled water by gently scraping the colony surface with a sterile glass rod. The suspension was collected in a tube and centrifuged at 8,000 rpm for $5 \mathrm{~min}$. The supernatant was discarded and the spore pellet was resuspended in $5 \mathrm{ml}$ aqueous solution of glycerol (30\% glycerol in sterile distilled water). The concentrations of spore suspensions were estimated using a hemacytometer and adjusted to $10^{7}$ spores $/ \mathrm{ml}$. The suspensions were stored at $-20^{\circ} \mathrm{C}$ until needed. The viability of the spores was confirmed whenever the stored suspension was used for inoculation. For this, a drop of spore suspension was put on a glass slide and left at room temperature for $24 \mathrm{~h}$. The germination percentage was then estimated under the microscope. Only samples with spore germination $\geq 85 \%$ were used in inoculations.

Identification of pathogenicity groups. Three B. napus differential cultivars, Westar, Glacier, and Quinta, were used to classify
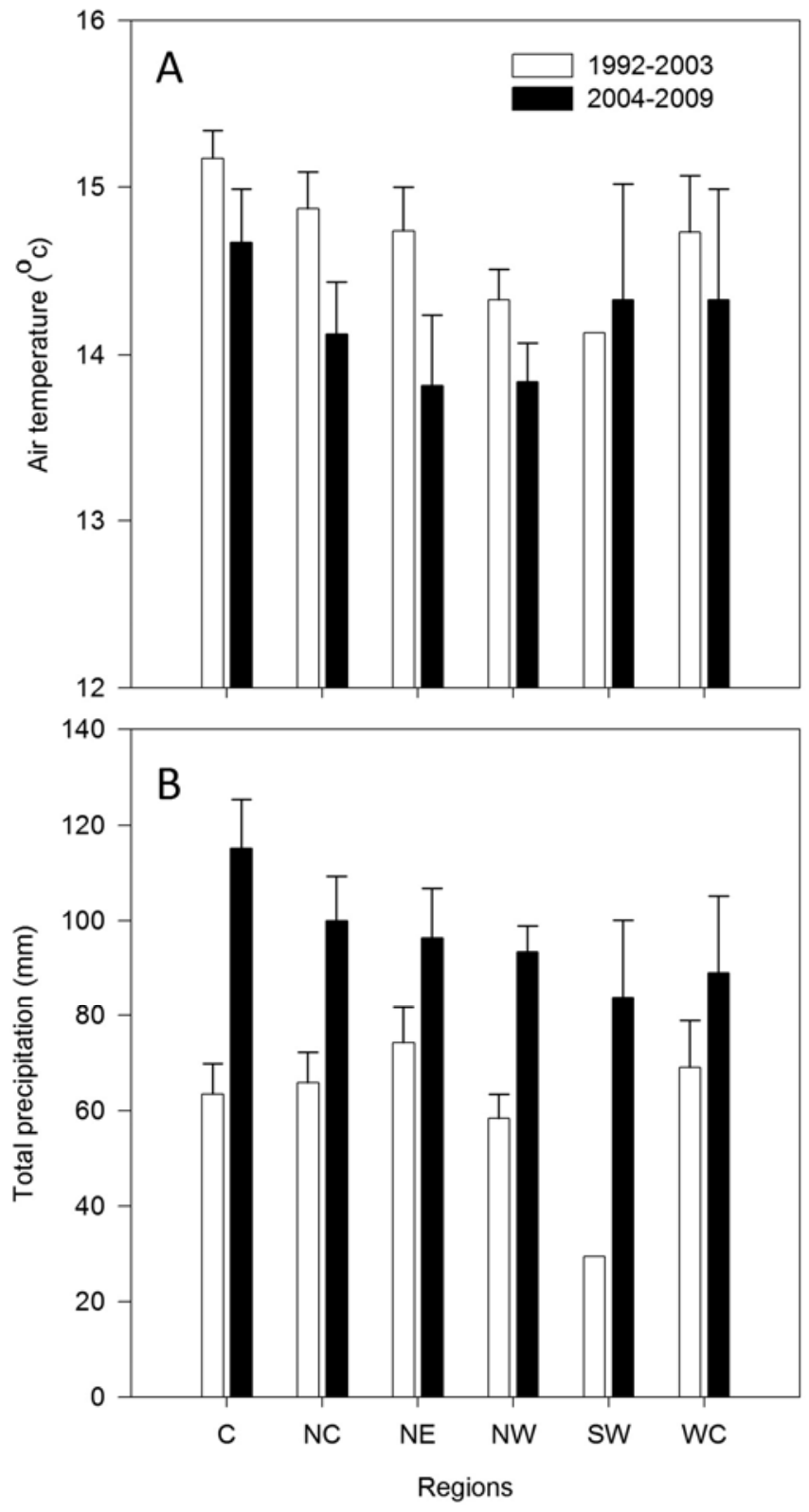

Fig. 2. Average $A$, air temperature $\left({ }^{\circ} \mathrm{C}\right)$ and $\mathbf{B}$, total precipitation $(\mathrm{mm})$ for the period between 15 May and 15 June of 1992-2003 and 2004-2009 in central (C), north central (NC), northeastern (NE), northwestern (NW), southwestern (SW), and west central (WC) North Dakota. Bars in each column represent the standard error of the mean. 
the isolates into pathogenicity groups (22). Cultivar Westar does not carry genes for resistance to $L$. maculans, while Glacier carries $R \operatorname{lm} 2$ and $R \operatorname{lm} 3$, and Quinta carries Rlm1 (3). Seeds of each differential were planted in plastic containers with 10 inserts and six wells in each insert. The containers were filled with greenhouse artificial soilless mix (Professional Growing Mix 1, SunGro Horticulture, Seba Beach, AB, Canada). Five days after planting, the seedlings were thinned to leave one healthy seedling per well. The seedlings were watered daily and kept in a greenhouse at $22 / 18^{\circ} \mathrm{C}$ day/night temperatures and 14-h photoperiod. Ten days after planting, each cotyledon was lightly pricked once with sterile sharp tweezers, and a 10- $\mu$ l aliquot of spore suspension was deposited on each wound. Each isolate was inoculated on triplicate sets of six seedlings per differential. Inoculated seedlings were incubated in mist chambers for $24 \mathrm{~h}$ and then returned to the greenhouse room. Fourteen days after inoculation, disease severity was scored using the 0 to 9 scale in which a 0 to 3 reaction was considered resistant (R), 4 to 6 intermediate (I), and 7 to 9 susceptible (S) (33). In this way, all three differentials are resistant to isolates from PG-1. Cultivar Westar is susceptible to isolates from PG-2, 3, T, and 4. Cultivar Glacier is resistant to isolates from PG-2, but susceptible to isolates from PG-3 and 4, and has intermediate reaction to isolates from PG-T. Cultivar Quinta is susceptible to isolates from PG-T and 4, but has intermediate reaction to isolates from PG-2 and $3(8,22)$.
Data analyses. Data from NDAWN stations were arbitrarily divided into six regions according to their geographic location in the state. Divide, Burke, Renville, Williams, Mountrail, and Ward counties were included in the northwest region; Bottineau, Rolette, McHenry, and Pierce counties in the north-central region; Towner, Cavalier, Ramsey, Benson, and Nelson counties in the northeast region; McLean in the west-central region; Sheridan, Wells, Foster, and Stutsman counties in the central region; and Hettinger in the southwest region. Air temperature (Celsius) and total precipitation $(\mathrm{mm})$ averages and their standard errors were calculated for the period between 15 May and 15 June of each year for each region using the means procedure of SAS (PROC MEANS, Ver. 9.3, SAS Institute, Inc., Cary, NC). A grand mean for years between 1992 and 2003 was calculated for each region and compared to that of the period between 2004 and 2009.

Fields within each county were divided into three groups based on the percentage of blackleg symptomatic plants observed by field. The arbitrary thresholds to separate these groups were $0 \%$, $\leq 30 \%$, and $>30 \%$ incidence. The percentage of fields in these groups was used to calculate the prevalence of fields with no, moderate, and severe blackleg incidences, respectively. A field was considered to have a blackleg outbreak when incidences were $>30 \%$. To further characterize the epidemics, the mean percentage of blackleg symptomatic stems and its standard deviation

Table 1. Blackleg (Leptosphaeria maculans) prevalence and incidence in commercial canola fields in North Dakota counties in 2004, 2007, and 2009

\begin{tabular}{|c|c|c|c|c|c|c|c|c|c|}
\hline \multirow[b]{3}{*}{ Years } & \multirow[b]{3}{*}{ Regions/Counties } & \multicolumn{4}{|c|}{ Blackleg prevalence } & \multicolumn{4}{|c|}{ Blackleg incidence } \\
\hline & & \multicolumn{3}{|c|}{ Fields with incidence } & \multirow[b]{2}{*}{ Total fields } & \multicolumn{2}{|c|}{$1-30 \%$} & \multicolumn{2}{|c|}{$>\mathbf{3 0} \%$} \\
\hline & & $\mathbf{0 \%}$ & $1-30 \%$ & $>\mathbf{3 0 \%}$ & & Mean & Std. dev. ${ }^{a}$ & Mean & Std. dev. \\
\hline \multirow[t]{28}{*}{2004} & Northwest & & & & & & & & \\
\hline & Burke & 7 & 0 & 0 & 7 & - & - & - & - \\
\hline & Divide & 3 & 0 & 0 & 3 & - & - & - & - \\
\hline & Mountrail & 10 & 0 & 0 & 10 & - & - & - & - \\
\hline & Renville & 16 & 0 & 0 & 16 & - & - & - & - \\
\hline & Ward & 17 & 0 & 0 & 17 & - & - & - & - \\
\hline & Williams & 2 & 0 & 0 & 2 & - & - & - & - \\
\hline & North central & & & & & & & & \\
\hline & Bottineau & 22 & 0 & 0 & 22 & - & - & - & - \\
\hline & Rolette & 8 & 1 & 0 & 9 & 2.0 & - & - & - \\
\hline & McHenry & 7 & 0 & 0 & 7 & - & - & - & - \\
\hline & Northeast & & & & & & & & \\
\hline & Benson & 6 & 9 & 0 & 15 & 7.6 & 6.54 & - & - \\
\hline & Cavalier & 5 & 20 & 7 & 32 & 10.5 & 6.86 & 59.7 & 22.19 \\
\hline & Nelson & 7 & 1 & 0 & 8 & 24.0 & - & - & - \\
\hline & Ramsey & 3 & 4 & 0 & 7 & 15.5 & 10.50 & - & - \\
\hline & Towner & 8 & 6 & 2 & 16 & 9.3 & 3.93 & 45.0 & 4.24 \\
\hline & West central & & & & & & & & \\
\hline & McLean & 18 & 0 & 0 & 18 & - & - & - & - \\
\hline & Central & & & & & & & & \\
\hline & Eddy & 0 & 1 & 0 & 1 & 6.0 & - & - & - \\
\hline & Foster & 2 & 1 & 0 & 3 & 2.0 & - & - & - \\
\hline & Sheridan & 1 & 3 & 0 & 4 & 4.0 & 3.46 & - & - \\
\hline & Stutsman & 1 & 1 & 0 & 2 & 26.0 & - & - & - \\
\hline & Wells & 2 & 3 & 0 & 5 & 7.3 & 4.62 & - & - \\
\hline & Southwest & & & & & & & & \\
\hline & Hettinger & 10 & 0 & 0 & 10 & - & - & - & - \\
\hline & Subtotal & 155 & 50 & 9 & 214 & - & - & - & - \\
\hline \multirow[t]{12}{*}{2007} & Northwest & & & & & & & & \\
\hline & Burke & 6 & 0 & 0 & 6 & - & - & - & - \\
\hline & Divide & 2 & 0 & 0 & 2 & - & - & - & - \\
\hline & Mountrail & 9 & 0 & 0 & 9 & - & - & - & - \\
\hline & Renville & 4 & 9 & 0 & 13 & 6.4 & 4.33 & - & - \\
\hline & Ward & 12 & 3 & 0 & 15 & 6.7 & 4.16 & - & - \\
\hline & Williams & 1 & 0 & 0 & 1 & - & - & - & - \\
\hline & North central & & & & & & & & \\
\hline & Bottineau & 2 & 10 & 2 & 14 & 11.0 & 8.12 & 60.0 & 28.28 \\
\hline & Rolette & 0 & 8 & 0 & 8 & 4.0 & 2.14 & - & - \\
\hline & McHenry & 2 & 3 & 0 & 5 & 11.3 & 16.17 & - & - \\
\hline & Pierce & 3 & 4 & 0 & 7 & 10.5 & 9.57 & - & - \\
\hline
\end{tabular}

\footnotetext{
${ }^{\text {a }}$ Std. dev. = Standard deviation of the mean; dash (-) indicates no fields present in these categories or values not calculated for subtotal or grand total
} rows. 
were calculated for the two categories in which blackleg incidence was $>0 \%$.

The median of disease severity for each isolate by differential interaction was calculated using the univariate procedure of SAS (PROC UNIVARIATE). These medians were used to determine the virulence phenotype of the isolates as described. Changes in the frequencies of occurrence of each PG over time were used to calculate Simpson's diversity $(D)$ and equitability $\left(E_{D}\right)$ indices. In this study, $D$ represents the probability that two isolates randomly collected in a sample belong to the same PG and range between 0 and 1 . Values closer to 1 suggest a less diverse population. $E_{D}$ also ranges between 0 and 1 , but represents the relative contribution of all PGs present in a sample to the variability of that sample. $E_{D}$ values closer to 1 suggest all PG are equally abundant in the sample. The indices were calculated as follows:

$$
D=\frac{1}{\sum_{i=1}^{s} p_{i}^{2}} \quad \text { and } \quad E_{D}=\frac{D}{S}
$$

where $D=$ Simpson's diversity index, $S=$ total number of species in the community (richness), $p_{i}=$ proportion of $S$ made up of the $i$ th species, and $E_{D}=$ equitability (evenness) (27).

\section{Results}

Air temperature and precipitation. In general, the 15 May to 15 June periods during 2004 to 2009 were cooler and wetter than the averages of the previous 12 years. During 2004 to 2009, the average air temperature across regions was $14.2^{\circ} \mathrm{C}$, while that for 1992 to 2003 was $14.7^{\circ} \mathrm{C}$ (Fig. 2A). Among regions, the northeast and northwest had the lowest mean air temperatures during 2004 to 2009 at $13.8^{\circ} \mathrm{C}$, although the largest change in mean temperature was observed in the northeast and north central regions with means that were 0.8 and $0.9^{\circ} \mathrm{C}$ lower than their 1992 to 2003 averages, respectively. The mean total precipitation across regions for the 15 May to 15 June period during 2004 to 2009 was $96 \mathrm{~mm}$, while the mean for the same period during 1992 to 2003 was $60 \mathrm{~mm}$ (Fig. 2B). The southwest region received an average of $84 \mathrm{~mm}$ of rain during the 15 May to 15 June period during 2004 to 2009; this mean was 2.8 times greater than the average for the same period during 1992 to 2003; however, the central, north central, and northeast regions were the wettest, receiving a mean total of 115,100 , and $96 \mathrm{~mm}$, respectively. These averages were $1.8,1.5$, and 1.3 times greater than their respective 1992 to 2003 averages.

Blackleg prevalence. Prevalence and incidence of blackleg were determined from 572 fields surveyed during 3 years of this study

Table 1. (continued from preceding page)

\begin{tabular}{|c|c|c|c|c|c|c|c|c|c|}
\hline \multirow[b]{3}{*}{ Years } & \multirow[b]{3}{*}{ Regions/Counties } & \multicolumn{4}{|c|}{ Blackleg prevalence } & \multicolumn{4}{|c|}{ Blackleg incidence } \\
\hline & & \multicolumn{3}{|c|}{ Fields with incidence } & \multirow[b]{2}{*}{ Total fields } & \multicolumn{2}{|c|}{$\mathbf{1 - 3 0 \%}$} & \multicolumn{2}{|c|}{$>\mathbf{3 0} \%$} \\
\hline & & $0 \%$ & $1-30 \%$ & $>30 \%$ & & Mean & Std. dev. ${ }^{a}$ & Mean & Std. dev. \\
\hline & \multicolumn{9}{|l|}{ Northeast } \\
\hline & Benson & 4 & 5 & 0 & 9 & 10.8 & 7.16 & - & - \\
\hline & Cavalier & 7 & 30 & 8 & 45 & 12.8 & 8.98 & 51.5 & 20.14 \\
\hline & Nelson & 4 & 0 & 0 & 4 & - & - & - & - \\
\hline & Ramsey & 0 & 8 & 1 & 9 & 14.8 & 8.75 & 70.0 & - \\
\hline & Towner & 2 & 8 & 9 & 19 & 5.5 & 3.96 & 50.4 & 20.02 \\
\hline & \multicolumn{9}{|l|}{ West central } \\
\hline & McLean & 2 & 5 & 2 & 9 & 8.4 & 1.67 & 84.5 & 20.51 \\
\hline & \multicolumn{9}{|l|}{ Central } \\
\hline & Foster & 2 & 0 & 0 & 2 & - & - & - & - \\
\hline & Sheridan & 3 & 0 & 0 & 3 & - & - & - & - \\
\hline & Stutsman & 1 & 0 & 0 & 1 & - & - & - & - \\
\hline & Wells & 2 & 0 & 0 & 2 & - & - & - & - \\
\hline & \multicolumn{9}{|l|}{ Southwest } \\
\hline & Hettinger & 2 & 2 & 0 & 4 & 9.0 & 7.07 & - & - \\
\hline & Subtotal & 70 & 95 & 22 & 187 & - & - & - & - \\
\hline \multirow[t]{28}{*}{2009} & \multicolumn{9}{|l|}{ Northwest } \\
\hline & Burke & 0 & 5 & 2 & 7 & 14.0 & 6.78 & 68.0 & 19.80 \\
\hline & Divide & 0 & 1 & 0 & 1 & 14.0 & - & - & - \\
\hline & Mountrail & 0 & 2 & 7 & 9 & 16.0 & 5.66 & 48.4 & 20.74 \\
\hline & Renville & 0 & 5 & 6 & 11 & 11.6 & 7.13 & 51.7 & 16.66 \\
\hline & Ward & 1 & 7 & 7 & 15 & 12.9 & 7.10 & 56.3 & 5.68 \\
\hline & Williams & 0 & 1 & 0 & 1 & 2.0 & - & - & - \\
\hline & \multicolumn{9}{|l|}{ North central } \\
\hline & Bottineau & 0 & 8 & 2 & 10 & 13.3 & 6.92 & 64.0 & 5.66 \\
\hline & Rolette & 0 & 9 & 0 & 9 & 8.4 & 7.60 & - & - \\
\hline & McHenry & 2 & 1 & 3 & 6 & 2.0 & - & 50.0 & 19.70 \\
\hline & Pierce & 0 & 4 & 1 & 5 & 14.0 & 12.75 & 84.0 & - \\
\hline & \multicolumn{9}{|l|}{ Northeast } \\
\hline & Benson & 4 & 0 & 0 & 4 & - & - & - & - \\
\hline & Cavalier & 15 & 25 & 0 & 40 & 5.1 & 4.17 & - & - \\
\hline & Nelson & 2 & 2 & 0 & 4 & 3.0 & 1.41 & - & - \\
\hline & Ramsey & 3 & 4 & 1 & 8 & 11.5 & 3.42 & 56.0 & - \\
\hline & Towner & 5 & 6 & 4 & 15 & 12.0 & 9.63 & 49.5 & 5.26 \\
\hline & \multicolumn{9}{|l|}{ West central } \\
\hline & McLean & 0 & 7 & 6 & 13 & 20.0 & 6.73 & 59.8 & 20.88 \\
\hline & \multicolumn{9}{|l|}{ Central } \\
\hline & Foster & 1 & 0 & 0 & 1 & - & - & - & - \\
\hline & Sheridan & 4 & 0 & 0 & 4 & - & - & - & - \\
\hline & Wells & 1 & 0 & 0 & 1 & - & - & - & - \\
\hline & \multicolumn{9}{|l|}{ Southwest } \\
\hline & Hettinger & 7 & 0 & 0 & 7 & - & - & - & - \\
\hline & Subtotal & 45 & 87 & 39 & 171 & - & - & - & - \\
\hline & Grand total & 270 & 232 & 70 & 572 & - & - & - & - \\
\hline
\end{tabular}


(Table 1). In 2004, 28\% of the 214 canola fields surveyed had blackleg symptomatic plants (Table 1). Approximately $85 \%$ of fields with blackleg had incidences ranging between 1 and $30 \%$, with an average incidence across counties of $10 \%$, although two of the fields, located in Stutsman and Nelson counties, had a mean blackleg incidence of $25 \%$. The remaining $15 \%$ had blackleg incidences greater than $30 \%$. These fields were located in Cavalier and Towner counties in northeastern North Dakota and had a mean incidence across counties of 52\%. In 2007, 63\% of the 187 fields surveyed had blackleg symptomatic plants. Approximately $81 \%$ of fields with blackleg had incidences ranging between 1 and 30\%, with an average incidence across counties of $9.3 \%$. The remaining
$19 \%$ had blackleg incidences greater than $30 \%$. These fields, which were located in Bottineau, Cavalier, and Ramsey counties in northeastern North Dakota and in McLean County in west-central North Dakota, had a mean incidence across counties of 63\%. In 2009, $74 \%$ of the 171 fields surveyed had blackleg symptomatic plants. Approximately $74 \%$ of fields with blackleg had incidences ranging between 1 and $30 \%$ with an average incidence across counties of $11 \%$. The remaining $26 \%$ had blackleg incidences greater than $30 \%$. These fields were spread in 10 counties in northwest, northcentral, northeastern, and west-central North Dakota and had a mean incidence across counties of $63 \%$. Region-wise, blackleg prevalence increased greatly between 2004 and 2009 in the north-

Table 2. Frequency of Leptosphaeria maculans pathogenicity groups identified from commercial canola fields in North Dakota counties in 2004, 2007, and 2009

\begin{tabular}{|c|c|c|c|c|c|c|c|c|}
\hline \multirow[b]{2}{*}{ Years } & \multirow[b]{2}{*}{ Regions/Counties } & \multirow[b]{2}{*}{ Isolates } & \multicolumn{6}{|c|}{ Pathogenicity groups } \\
\hline & & & 1 & 2 & 3 & 4 & $\mathbf{T}$ & ND $^{\mathrm{a}}$ \\
\hline \multirow[t]{18}{*}{2004} & Northwest & & & & & & & \\
\hline & Burke & 5 & 1 & $-^{\mathrm{b}}$ & 1 & 3 & - & - \\
\hline & Renville & 1 & - & - & - & 1 & - & - \\
\hline & Ward & 1 & - & - & - & 1 & - & - \\
\hline & Williams & 1 & - & - & - & - & 1 & - \\
\hline & North central & & & & & & & \\
\hline & Bottineau & 7 & - & - & 2 & 4 & - & 1 \\
\hline & McHenry & 5 & - & - & 1 & 3 & 1 & - \\
\hline & Northeast & & & & & & & \\
\hline & Benson & 3 & - & - & - & 2 & - & 1 \\
\hline & Cavalier & 8 & 2 & - & - & 5 & - & 1 \\
\hline & Ramsey & 7 & - & - & 1 & - & - & 6 \\
\hline & Towner & 2 & - & - & - & 2 & - & - \\
\hline & West central & & & & & & & \\
\hline & McLean & 4 & - & - & 1 & 2 & - & 1 \\
\hline & Southwest & & - & - & - & - & - & - \\
\hline & Hettinger & 6 & - & - & - & 2 & - & 4 \\
\hline & Subtotal & 50 & 3 & 0 & 6 & 25 & 2 & 14 \\
\hline \multirow[t]{20}{*}{2007} & Northwest & & & & & & & \\
\hline & Ward & 3 & - & - & - & 3 & - & - \\
\hline & Williams & 4 & 1 & - & - & 1 & 1 & 1 \\
\hline & North central & & & & & & & \\
\hline & Bottineau & 2 & - & - & - & 2 & - & - \\
\hline & Rolette & 5 & - & - & - & 5 & - & - \\
\hline & McHenry & 1 & - & - & - & 1 & - & - \\
\hline & Northeast & & & & & & & \\
\hline & Benson & 1 & - & - & - & 1 & - & - \\
\hline & Cavalier & 11 & 3 & - & - & 6 & - & 2 \\
\hline & Grand Forks & 4 & 2 & - & - & 1 & - & 1 \\
\hline & Nelson & 6 & - & - & - & 6 & - & - \\
\hline & Pembina & 2 & - & - & 1 & - & - & 1 \\
\hline & Towner & 3 & - & - & 1 & 1 & - & 1 \\
\hline & West central & & & & & & & \\
\hline & McLean & 9 & - & - & - & 8 & - & 1 \\
\hline & Central & & & & & & & \\
\hline & Foster & 1 & - & - & 1 & - & - & - \\
\hline & Wells & 5 & - & 1 & - & 3 & - & 1 \\
\hline & Subtotal & 57 & 6 & 1 & 3 & 38 & 1 & 8 \\
\hline \multirow[t]{17}{*}{2009} & Northwest & & & & & & & \\
\hline & Burke & 10 & 1 & - & - & 5 & 1 & 3 \\
\hline & Divide & 3 & - & - & 2 & - & - & 1 \\
\hline & Mountrail & 3 & - & - & - & 3 & - & - \\
\hline & Renville & 16 & - & 1 & 1 & 8 & 2 & 4 \\
\hline & Ward & 10 & - & - & - & 4 & 3 & 3 \\
\hline & North central & & & & & & & \\
\hline & Bottineau & 15 & 1 & - & - & 9 & 4 & 1 \\
\hline & McHenry & 10 & - & - & - & 8 & 2 & - \\
\hline & Pierce & 2 & - & - & - & - & - & 2 \\
\hline & Northeast & & & & & & & \\
\hline & Cavalier & 14 & - & - & - & 8 & 3 & 3 \\
\hline & Towner & 6 & - & - & 1 & 3 & - & 2 \\
\hline & West central & & & & & & & \\
\hline & McLean & 20 & - & - & 3 & 11 & - & 6 \\
\hline & Subtotal & 109 & 2 & 1 & 7 & 59 & 15 & 25 \\
\hline & Grand total & 216 & 11 & 2 & 16 & 122 & 18 & 47 \\
\hline
\end{tabular}

\footnotetext{
a Pathogenicity groups not determined.
}

b Pathogenicity group not present. 
western, north-central, and west-central regions, going from 0,3 , and $0 \%$ in 2004 to 98,93 , and $100 \%$ in 2009, respectively (Table 1). The mean blackleg prevalence in the northeast region was $63 \%$ in $2004,80 \%$ in 2007, and $59 \%$ in 2009. Blackleg prevalence in the central and southwestern regions was zero in 2 of the 3 years in which samples were collected; these two regions also had the smallest number of fields scouted in each of the 3 years.

Pathogenicity groups prevalence. The virulence phenotypes of 216 isolates were determined during the 3 years of the study; 169 of them were classified into known PGs, but 47 isolates had virulence phenotypes that did not fit the established PG phenotypes (Table 2). PG-1 isolates accounted for 6,11 , and $2 \%$ of isolates evaluated in 2004, 2007, and 2009, respectively. PG-1 isolates were retrieved from samples collected from two counties in 2004 and 2009 and from three counties in 2007. Isolates from PG-2 could not be detected in samples collected in 2004 but were present in samples collected from Wells County in 2007 and from Renville County in 2009. PG-2 isolates accounted for $<2 \%$ of the isolates phenotyped in this study.

PG-3 isolates accounted for approximately 12, 5, and $6 \%$ of all isolates evaluated in 2004, 2007, and 2009, respectively. In 2004, PG-3 isolates were present in samples from five of the 12 counties visited that year. In 2007, PG-3 isolates were detected in samples from three of the 14 counties visited that year. In 2009, PG-3 isolates were retrieved from four of the 11 counties sampled, although almost $40 \%$ of all PG-3 isolates were retrieved from samples collected in McLean County.

PG-4 isolates accounted for 50, 67, and 54\% of all isolates evaluated in 2004, 2007, and 2009, respectively. In 2004, PG-4 isolates were retrieved from samples collected in 10 of the 12 counties sampled. Approximately 20 and $16 \%$ of all PG-4 isolates retrieved that year came from Cavalier and Bottineau counties. In 2007, PG-4 isolates were retrieved from samples from 12 of the 14 counties sampled. Approximately $22 \%$ of these isolates came from McLean County, while Cavalier and Nelson counties accounted for $16 \%$ each. In 2009, PG-4 isolates were retrieved from nine of the 11 counties from which isolates were tested. Approximately $17 \%$ of all PG-4 isolates identified in 2009 came from McLean County, although Bottineau, McHenry, Renville, and Cavalier accounted for $15,14,14$, and $14 \%$, respectively.

PG-T isolates accounted for 4, 2, and $14 \%$ of all isolates evaluated in 2004, 2007, and 2009, respectively. In 2004, PG-T was detected in samples from two of the 12 counties visited; these counties are located in the west-central and southwestern portions of the state. In 2007, the only PG-T isolate identified came from Williams County in the northwestern corner of the state. In 2009, PG-T isolates were retrieved from six of the 11 counties visited that year, although almost one-half of all isolates in this group were retrieved from samples collected in Bottineau, Ward, and Cavalier counties.

Region-wise, 64 and $27 \%$ of all PG-1 isolates were retrieved from the northeastern and northwestern regions, respectively. The PG-2 isolates identified in this study were retrieved from two samples collected in 2007 from the central and southwestern regions. PG-3 was equally prevalent in the northwest, northeast, and westcentral regions, each accounting for approximately $25 \%$ of all PG-3 isolates, while the north-central region accounted for 19\%. PG-4 isolates were more prevalent in the northern regions of the state, with the northeastern region accounting for $29 \%$ of them, followed by the north-central and northwestern regions with 26 and $24 \%$, respectively. PG-T was prevalent only in the northern regions; the northwestern region accounted for $44 \%$ of all PG-T, followed by the north-central region with $39 \%$ and the northeast region with $17 \%$.

Equitability index. Changes in the number of pathogenicity groups as well as in their relative prevalence over the time covered by this study were reflected in the Simpson's equitability index. The indices for 2004, 2007, and 2009 were 0.48, 1.35, and 0.45, respectively. The index for 2007 was significantly different from the indices for 2004 and $2009(P<0.0001)$.

\section{Discussion}

Blackleg is resurging as a major problem for North Dakota canola producers. Results of this study show blackleg prevalence has steadily increased since 2004, while strains of PG-3, PG-4, and PG-T are becoming prevalent in more counties. At the same time, the proportion of fields experiencing severe blackleg outbreaks, incidences greater than $30 \%$, increased from $4 \%$ in 2004 to $23 \%$ in 2009 .

Several factors may have contributed to the rapid expansion of blackleg. However, the most important factor could have been the confluence of favorable environmental conditions and cultivation of susceptible cultivars. The average air temperature for 15 May to 15 June was $0.5^{\circ} \mathrm{C}$ cooler between 2004 and 2009 than in the previous 11 years. These averages were within the optimum range for spore release (31). The biggest and most important environmental difference, however, was observed in precipitation. Total precipitation for the period in which disease data were collected was in general 1.6 times greater than that of the previous 12 years. Further, the 15 May to 15 June period during 2004 to 2009 had an average of 5.3 rainy days dropping $\geq 5 \mathrm{~mm}$ of precipitation compared to the 1992 to 2003 period which had an average of 3.7 such days (data not shown). These conditions resulted in a more conducive environment for infection and occurred when plants were at their most susceptible stages (31). Most commercially available canola cultivars planted in the region are considered resistant or moderately resistant to PG-2 but susceptible to PG-3 and PG-4 strains of blackleg (19). The differential cultivar Glacier, which carries resistance genes $R \operatorname{lm} 2$ and $R \operatorname{lm} 3$, is resistant to PG-2 but susceptible to PG-3 and PG-4, while the differential Quinta, which carries resistance gene $R \operatorname{lm} 1$, has an intermediate reaction to PG-2 and PG-3 but is susceptible to PG-T and PG-4 (3). Thus, canola cultivars planted in the region probably carry resistance genes $R l m 1$, $R \operatorname{lm} 2$, and/or $R \operatorname{lm} 3$, which are ineffective against PG-T and PG-4.

Another factor that may have contributed to the increased prevalence of blackleg is the shortening of crop rotations to increase canola production as a result of higher demand and market prices for the commodity. This is especially evident in the northeast region. In 2004, approximately $31 \%$ of the area planted to canola in North Dakota was located in its northeast region; that share has increased to an average of $40 \%$ in the last 3 years, while the share of other regions has remained more or less stable (30). Since the pathogen survives on crop residues (32), shortening rotations increases the probability that larger amounts of inoculum from the previous season will be available for infection during the next season. A third factor may be the increased movement of harvested seeds as well as seed trade within counties. Infected and/or contaminated seeds can spread the pathogen into new areas $(11,18,23,25)$. Infected seeds that fall from harvesting equipment on roadsides may germinate the following summer and serve as sources of inoculum from which spores may be dispersed into neighboring fields $(21,24)$ so effectively that distances of no less than $5 \mathrm{~km}$ would be considered effective to isolate a field from incoming inoculum (5). In northern North Dakota, canola production fields are usually located less than $5 \mathrm{~km}$ apart. While most certified seeds are treated with a combination of fungicides and insecticides that reduce the risk of pathogen spread, seed treatments do not eliminate the risk completely.

At the same time that blackleg prevalence increased, blackleg incidence was also on the rise. In 2004, most of the fields where disease was present had incidences $<30 \%$. Only nine fields in two counties, Cavalier and Towner, had disease incidence greater than $30 \%$. These two counties had average disease incidences of 60 and $45 \%$, respectively. Our data also show that $63 \%$ of the isolates tested from Cavalier County and all the isolates tested from Towner County belong to PG-4. These results are in contrast with the findings of Chen and Fernando (8), who did not detect PG-4 among $L$. maculans isolates collected in 2004 from North Dakota counties from which we also collected samples that year. The relatively small amount of information provided by Chen and Fernando (8) on the origin of their isolates makes explaining this difference 
difficult. However, they are very likely due to differences in sampling procedures. In our study, one field was scouted for every 2,025 ha of canola planted in a given county. In this way, 32 fields were scouted for blackleg in Cavalier County in 2004, while only 16 fields were visited in Towner County that year. All isolates used in our study were collected from stem cankers located in the crown area, and only one isolate per field was inoculated on the differentials. Chen and Fernando (8) indicated they used a combination of leaf and stem isolates and did not specify how many fields were represented. In 2007, 22 fields in three other counties, Bottineau, McLean, and Ramsey, had disease incidences greater than $30 \%$, with the highest mean incidence at $85 \%$. Results of our study indicate PG-3 and PG- 4 were already present in Bottineau and McLean counties in 2004. Further, in 2004, PG-3 was also present in Ramsey County, while PG-T was detected in McLean County. In 2009, 39 fields in six additional counties had disease incidence greater than $30 \%$, with the highest mean incidence at $84 \%$. In all these counties, PG-3, PG-4, and PG-T were detected alone or in combinations with each other. Soon after the blackleg epidemics of the early 1990s (15), canola breeders developed cultivars with resistance to the then predominant PG-2. By 1998, most cultivars in use were resistant or moderately resistant to PG-2 (4). The rise of PGs capable of defeating currently used resistance genes coupled with limited availability of fungicides (9) may have contributed to the increase in disease incidences.

The equitability index for the North Dakota population of $L$. maculans between 2004 and 2009 was greater than that of the period between 1984 and 2003 as calculated using data from Chen and Fernando (8). A higher index indicates more equal distribution of PGs in later years. Until 2003, the population was composed mostly by PG-1 and PG-2 isolates, with the latter being the most common pathotype (8). The presence of PG-3, PG-4, and PG-T was reported in 2003 in few canola growing counties in North Dakota $(6,8,9)$. However, the frequency of occurrence of these PGs was very low (8). Our study shows the prevalence of PG-2 has significantly decreased and PG- 4 has become the predominant pathotype, with PG-3 and PG-T being equally prevalent in second place. The weakly virulent pathotype PG-1 was the least prevalent group in all years, probably because the isolates used in this study were retrieved from canola stems and PG-1 strains are foliar rather than stem pathogens (12).

The changes in PG prevalence reported in this study reflect the history of canola cultivar deployment in North Dakota and the ability of this pathogen to develop new virulence phenotypes (3). Westar, a cultivar with no blackleg resistance genes, was the most popular genotype planted in the early years. In 1991, a severe epidemic attributed to PG-2 affected canola fields in the state (16). Westar, which had by then been almost completely replaced by resistant cultivars in Canada (13), also was promptly replaced in North Dakota. The ability of L. maculans to quickly overcome genetic resistance has been well documented in France and Australia. In Australia, resistance was overcome within 3 years from the release of cultivars carrying the single dominant gene LepR3 derived from $B$. rapa subsp. sylvestris $(17,29,34)$, whereas in France resistance derived from $B$. juncea and $B$. nigra was overcome within 4 years (7).

Because of the increasing frequency of more aggressive and unknown pathotypes, North Dakota canola production is in a vulnerable phase. Until resistance genes other than $R \operatorname{lm} 1, R \operatorname{lm} 2$, and $R \operatorname{lm} 3$ are incorporated into commercial cultivars, immediate enforcement of current management practices is necessary to avoid a serious disease outbreak in the near future. This demands a serious effort to manage this disease either by deploying resistant cultivars with quantitative resistance or by other managerial practices such as longer crop rotation, better crop residue management, and fungicide application.

\section{Acknowledgments}

We thank Curt Doetkott for his help in writing the SAS code needed to summarize the weather data, and we dedicate this publication to the memory of the late Howard Arthur Lamey. This research was supported in part with funds from NIFA Award 2011-38624-30812.

\section{Literature Cited}

1. Allard, L. M., Brun, H., Jouffret, P., Lagarde, F., Penaud, A., Pinochet, X., Simonin, P., and Taverne, M. 2002. Les maladies du colza. Les Points Techniques du CETIOM.

2. Aubertot, J.-N., Pinochet, X., and Doré, T. 2004. Analyses of the effects of sowing date and nitrogen availability during vegetative stages of Phoma stem canker (Leptosphaeria maculans) development on two winter oilseed rape cultivars. Crop Prot. 23:635-645.

3. Balesdent, M. H., Barbetti, M. J., Li, H., Sivasithamparam, K., Gout, L., and Rouxel, T. 2005. Analysis of Leptosphaeria maculans race structure in a worldwide collection of isolates. Phytopathology 95:1061-1071.

4. Berglund, D. R. 1999. 1998 canola variety trials. Coop. Ext. Bull. A-1124 (Revised). North Dakota State University, Fargo, ND.

5. Bokor, A., Barbetti, M. J., Brown, A. G., McNish, G. C., and Wood, P. M. 1975. Blackleg of rapeseed. J. Agric. West. Aust. 16:7-10.

6. Bradley, C. A., Parks, P. S., Chen, Y., and Fernando, W. G. D. 2005. First report of pathogenicity groups 3 and 4 of Leptosphaeria maculans on canola in North Dakota. Plant Dis. 89:776.

7. Brun, H., Levivier, S., Somda, I., Ruer, D., Renard, M., and Chevre, A. M. 2000. A field method for evaluating the potential durability of new resistance sources: Application to the Leptosphaeria maculans-Brassica napus pathosystem. Phytopathology 90:961-966.

8. Chen, Y., and Fernando, W. G. D. 2006. Prevalence of pathogenicity groups of Leptosphaeria maculans in western Canada and North Dakota, USA. Can. J. Plant Pathol. 28:533-539.

9. del Rio Mendoza, L. E., Nepal, A., and Markell, S. 2012. Outbreak of blackleg in canola in North Dakota is caused by new pathogenicity groups. Online. Plant Health Progress doi:10.1094/PHP-2012-0410-01-RS

10. Fitt, B. D. L., Brun, H., Barbetti, M. J., and Rimmer, S. R. 2006. Worldwide importance of phoma stem canker (Leptosphaeria maculans and Leptosphaeria biglobosa) on oilseed rape (Brassica napus). Eur. J. Plant Pathol. 114:3-15.

11. Gabrielson, R. L. 1983. Blackleg disease of crucifers caused by Leptosphaeria maculans (Phoma lingam) and its control. Seed Sci. Technol 11:749-780.

12. Howlett, B. J., Idnurm, A., and Pedras, M. S. C. 2001. Leptosphaeria maculans, the causal agent of blackleg disease of Brassicas. Fung. Genet. Biol. 33:1-14.

13. Juska, A., Busch, L., and Tanaka, K. 1997. The blackleg epidemic in Canadian rapeseed as a "normal agricultural accident". Ecol. App. 7:1350-1356.

14. Khangura, R. K., and Barbetti, M. 2001. Prevalence of blackleg (Leptosphaeria maculans) on canola (Brassica napus) in Western Australia. Aust. J. Exp. Agric. 41:71-80.

15. Lamey, H. A. 1995. Blackleg and Sclerotinia disease of canola in North Dakota in 1991 and 1993. Plant Dis. 79:322-324.

16. Lamey, H. A., and Hershman, D. E. 1993. Canola (Brassica napus L.) blackleg caused by Leptosphaeria maculans in North Dakota. Plant Dis. $77: 1263$.

17. Li, H., Sivasithamparam, K., and Barbetti, M. J. 2003. Breakdown of a Brassica rapa subsp. sylvestris single dominant blackleg resistance gene in B. napus rapeseed by Leptosphaeria maculans field isolates in Australia. Plant Dis. 87:752.

18. Lloyd, A. B. 1959. The transmission of Phoma lingam (Tode) Desm. in the seeds of swede, turnip, chou moellier, rape and kale. N.Z. J. Agric. Res. 2:649-658.

19. Marino, D. 2011. Screening of germplasm accessions from Brassica species for resistance against PG3 and PG4 isolates of blackleg. M.S. thesis. North Dakota State University, Fargo, ND.

20. Markell, S., del Rio, L., Halley, S., Mazurek, S., Mathew, F., and Lamey, A. 2008. Blackleg of canola. N.D. State Univ. Ext. Serv. Publ. PP-1367.

21. McGee, D. C., and Emmett, R. W. 1977. Blackleg (Leptosphaeria maculans (Desm.) Ces. et de Not.) of rapeseed in Victoria: Crop losses and factors which affect disease severity. Aust. J. Agric. Res. 28:47-51.

22. Mengistu, A., Rimmer, S. R., Koch, E., and Williams, P. H. 1991. Pathogenicity grouping of isolates of Leptosphaeria maculans on Brassica napus cultivars and their disease reaction profiles on rapid-cycling brassicas. Plant Dis. 75:1279-1282.

23. Petrie, G. A. 1978. Occurrence of a highly virulent strain of blackleg (Leptosphaeria maculans) on rape in Saskatchewan (1975-77). Can. Plant Dis. Surv. 58:21-25.

24. Petrie, G. A. 1979. Prevalence of a highly virulent strain of Leptosphaeria maculans (blackleg) in seed samples of rape and turnip rape produced in Western Canada in 1976 and 1977. Can. J. Plant Sci. 59:899-901.

25. Petrie, G. A., and Vanterpool, T. C. 1974. Infestation of crucifer seed in Western Canada by the blackleg fungus Leptosphaeria maculans. Can. Plant Dis. Surv. 54:119-123.

26. Shoemaker, R. A., and Brun, H. 2001. The teleomorph of the weakly aggressive segregate of Leptosphaeria maculans. Can. J. Bot. 79:412-419.

27. Simpson, E. H. 1949. Measurement of diversity. Nature 163:688.

28. Sivasithamparam, K., Barbetti, M. J., and Li, H. 2005. Recurring challenges 
from a necrotrophic fungal plant pathogen: A case study with Leptosphaeria maculans (causal agent of blackleg disease in Brassica) in Western Australia. Ann. Bot. 96:363-377.

29. Sprague, S. J., Balesdent, M. H., Brun, H., Hayden, H. L., Marcroft, S. J., Pinochet, X., Rouxel, T., and Howlett, B. J. 2006. Major gene resistance in Brassica napus (oilseed rape) is overcome by changes in virulence of populations of Leptosphaeria maculans in France and Australia. Eur. J. Plant Pathol. 114:33-40.

30. U.S. Dep. Agric.-NASS cited. 2013. Quick Stats: Agricultural Statistics Data Base. Available online at http://quickstats.nass.usda.gov/

31. West, J. S., Kharbanda, P. D., Barbetti, M. J., and Fitt, B. D. L. 2001. Epide- miology and management of Leptosphaeria maculans (Phoma stem canker) on oilseed rape in Australia, Canada and Europe. Plant Pathol. 50:10-27.

32. Williams, P. H. 1992. Biology of Leptosphaeria maculans. Can. J. Plant Pathol. 14:30-35.

33. Williams, P. H., and Delwiche, P. A. 1980. Screening for resistance to blackleg of crucifers in the seedling stage. Pages 164-170 in: Proc. Eucarpia Cruciferae 1979 Conference. Wageningen, Netherlands.

34. Yu, F. Q., Lydiate, D. J., and Rimmer, S. R. 2004. Identification and mapping of a third blackleg resistance locus in Brassica napus derived from B. rapa subsp. sylvestris. In: Plant Anim. Genome XII Conf. San Diego, CA. 